\title{
INFLUENCE OF SELF-ESTEEM AND OBJECTIVE KNOWLEDGE FINANCIAL OF THE FINANCIAL BEHAVIOR IN YOUNG ADULTS WITH SUBJECTIVE FINANCIAL KNOWLEDGE MEDIATION AS VARIABLE
}

\author{
Rex Gosal', Dewi Astuti ${ }^{2}$, Evelyn ${ }^{3}$ \\ 1,2,3 Finance and Investment Program, Faculty of Business and Economics, Petra Christian University \\ Jl. Siwalankerto 121-131, Surabaya

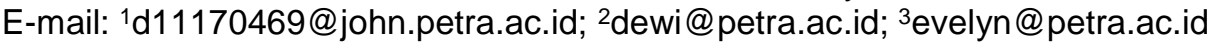

\begin{abstract}
This study aims to determine the effect of self-esteem and objective financial knowledge on financial behavior. In addition, this study also seeks to assess the impact of subjective financial knowledge as a mediating variable between self-esteem and objective financial knowledge on financial behavior. The population of this research is young adults in Surabaya. The research sample is the population aged 25-34 years and invested in stocks for less than three years. Data analysis method used is partial least square analysis. The results showed that self-esteem had a significant effect on financial behavior, objective financial knowledge had no considerable impact on financial behavior, subjective financial knowledge had a significant effect on financial behavior, selfesteem, and financial. In addition, objective knowledge has a significant effect on subjective financial knowledge, and self-esteem and financial knowledge objective have a significant impact on financial behavior with financial knowledge subjective as a mediating variable.
\end{abstract}

Keywords: Financial Behavior, Self-Esteem, Knowledge of Financial Objectives, Financial Knowledge, Subjective Young Adults.

\section{INTRODUCTION}

Young adults are facing a period of transition from adolescence to adulthood. Scheresberg (2013) states that the age range of Young Adults starts from the age of 25 years to 34 years. Research by Arnett et al. (2014) states that Young Adults are the most unstable period in a person's life. This is because this period is a time of adjusting to lifestyles and facing new challenges, which are passed alone for the first time without parents (Srivastava \& Agarwal, 2013). According to Bapat (2020), Young Adults will encounter many complicated financial situations and take many financial decisions to overcome these challenges. Therefore, young adults need to build financial behavior responsibly (Malelak \& Halim, 2021).

According to various surveys and studies, young adults have worrying financial behavior. For example, a study conducted by Schwab Moneywise (2009) found that many young adults feel they are not sufficiently prepared to make good financial decisions. In addition, Scheresberg (2013) research found that young adults tend to have no idea and plan for retirement and do not have savings for an emergency fund. The phenomenon in Indonesia also supports the statement above in early 2021, where many young adults started investing in stocks due to the rise of artists. The influencers recommended stocks of certain companies whose prices rose sharply in a short period to make them look very attractive to the public investors (Febrian, 2021). This phenomenon causes investors young adults to act impulsively for fear of missing out on the opportunity to earn big profits in a short time (Nurdiana, 2021). This fear also causes many investors to young adults, to use funds that should be used to meet their daily needs and even take large debts to invest (Wareza, 2021). According to Mahrofi (2021), people affected by this phenomenon tend to buy shares at an already high price, so their investment returns will not be optimal. In other words, many young adults affected by this phenomenon suffer losses.

In addition, there is also a study by Ramadhan \& Asandimitra (2019), which examines the determinants of financial behavior in the city of Surabaya. In this study, it is said that people aged 25 to 34 years (young adults) are the most active people using the internet. Using the internet itself has both positive and negative impacts. The positive impact is that the movement and growth of young adults are very fast with accessible communication, information seeking, and easy 
transactions, but this also makes Young Adults very consumptive with ease of shopping and making purchases. However, Rizkiawati \& Asandimitra's (2018) research also found that young adults in Surabaya also do not have responsible financial behavior. Young adults found that most of young adults Surabaya often does not set aside money for savings and investments and usually pay obligations and debts on time.

One of the factors determining financial behavior is financial knowledge (Hilgert, Hogarth, \& Beverly, 2003; Claudia \& Evelyn, 2021). According to Alba \& Hutchinson (2000), financial knowledge can be divided into two dimensions, namely objective and subjective. Objective financial knowledge refers to an individual's competence in the context of his knowledge of finance. Subjective financial knowledge refers to the individual's confidence in their understanding of finance.

However, financial knowledge is not the only determinant of financial behavior. Abreu \& Mendes (2012) stated that psychological factors significantly influence financial behavior. In addition, Tang et al. (2015) also said that for someone to go through the behavior change stage, they need to have psychological knowledge and readiness. One of the psychological factors that have a relationship with financial behavior is self-esteem (Javed, Degong, \& Qadeer, 2017).

This study refers to previous research conducted by Tang \& Baker (2016), which examined selfesteem, financial knowledge, and financial behavior in the United States. This study will use selfesteem and financial knowledge objectives as independent variables that affect financial behavior, with subjective financial knowledge as a mediating variable. The difference between this research and previous research lies in the research object, namely young adults.

This research was conducted on young adults who are novice investors in Surabaya because generally, young adults are characterized as having financial behavior irresponsible, and novice investors tend to be easily influenced by stock recommendations from artists and influencers (Febrian, 2021; Nurdiana, 2021; Mahrofi, 2021).

\section{LITERATURE REVIEW}

\section{The Financial Behavior}

Theory of planned behavior (TPB) is one of the theories commonly used to explain financial behavior. Xiao (2008) states that financial behavior can be defined as all human behavior related to financial management. Dew \& Xiao (2011) formed the "Financial Management Behavior Scale" to measure economic behavior responsible, consisting of 5 indicators: consumption, cash-flow management, savings and investment, credit management, and insurance.

\section{Objective Financial Knowledge}

Financial knowledge is rooted in individual competencies in the context of their understanding of finance (Alba \& Hutchinson, 2000). According to Javed, Degong, \& Qadeer (2017), objective financial knowledge is what one knows about financial concepts. Van Rooij, Lusardi, \& Alessie (2011) and Tang \& Baker (2016) say that the objective financial knowledge can be measured using questions about basic financial concepts.

\section{Subjective Financial Knowledge}

Subjective financial knowledge stems from individuals' confidence in their knowledge about finance (Alba \& Hutchinson, 2000). According to Tang \& Baker (2016), subjective financial knowledge refers to perception and confidence about managing finance. Perry \& Morris (2005) said that a selfassessed knowledge rating scale could measure subjective financial knowledge with individuals about several financial concepts. 


\section{Self-Esteem}

Rosenberg, Schooler, Schoenbach, \& Rosenberg (1995) stated that self-esteem is a person's attitude towards himself. According to Srivastava \& Agarwal (2013), Self-Esteem is broadly selfevaluation, both positive and negative. According to Rosenberg, Schooler, Schoenbach, \& Rosenberg (1995), Self-Esteem is measured by the scale self-esteem, or known as Rosenberg SelfEsteem. This scale measures positive and negative feelings in a person.

\section{Relationship Between Concepts}

\section{a. Effect of Self-Esteem on Financial Behavior}

In establishing the relationship between self-esteem and financial behavior, Tang and Baker (2016) explain that high self-esteem operates as an emotional resource that a person uses to get through the financial management process. By going through various financial management processes, a person can hone his behavior to make the right financial decisions, resulting in financial behavior responsible (Topa, Hernández-Solís, \& Zappalà, 2018).

\section{b. Effect of Objective Financial Knowledge on Financial Behavior}

In general, an increase in objective financial knowledge will result in responsible financial behavior (Tang, Baker, \& Peter, 2015; Gabriel \& Linawati, 2020). To apply financial behavior, one should know financial concepts to not commit mistakes in managing their finances. According to Hilgert, Hogarth, \& Beverly (2003), someone who has a high level of financial knowledge tends to show financial behavior. This is because everyone who has objective financial knowledge will become more aware of the behavior and actions that are taken to manage their finances and know the risks that occur if they do not carry out financial behavior responsibly.

\section{c. Effect of Self-Esteem on Financial Behavior mediated by Subjective Financial Knowledge}

Self-esteem can indirectly affect financial behavior through subjective financial knowledge as mediation. Someone with high self-esteem will feel confident in their knowledge and have a high subjective evaluation of financial knowledge (Tang \& Baker, 2016). This is because both are a person's subjective evaluation of aspects of a person's self, where self-esteem is an evaluation of all aspects of a person's self-such as appearance, abilities, knowledge, and personality (Srivastava \& Agarwal, 2013). While subjective financial knowledge is an evaluation of aspects of one's knowledge about finance. In other words, having an overall high assessment (self-Self-Esteem) will simultaneously increase the assessment of one's financial knowledge (subjective financial knowledge) (Tang \& Baker, 2016). Research Lind et al. (2020) stated that subjective financial knowledge is an essential determinant for someone to produce financial behavior responsibly. Having high subjective financial knowledge will encourage someone to know financial information, deal with financial situations, and perform financial management to build financial behavior more responsible.

\section{d. Effect of Objective Financial Knowledge on Financial Behavior Mediated by Subjective Financial Knowledge}

According to Bandura (1982), one needs to understand financial concepts before engaging in responsible financial behavior. But even knowing what to do doesn't define responsible behavior. The previous research, Tang \& Baker (2016), said that the effect of objective financial knowledge could be insignificant because there is no subjective variable financial knowledge to help describe the impact of objective financial knowledge on financial behavior. According to his research, someone with a high level of objective financial knowledge does not necessarily have a high level of confidence in his financial knowledge. This makes a person tend to avoid the financial management process because they feel they do not have enough knowledge to go through it, so they cannot hone and practice financial behavior responsibly. However, suppose someone has high subjective 
financial knowledge. In that case, they tend to be more able to build financial behavior more responsibly because they are more interested in knowing financial information, dealing with financial situations, and managing finances (Lind et al., 2020; Basana and Tarigan, 2021).

\section{METHODOLOGY}

This research uses associative method. Associative research aims to determine the effect or relationship between two or more variables (Sugiyono, 2019). Data processing in this study will use structural equation modeling analysis (Structural Equation Modeling /SEM). The population from this study is young adults who are domiciled in Surabaya. Therefore, researchers targeted the criteria for the sample of young adults because financial behavior in that age range is still irresponsible (Schwab Moneywise, 2009; Ludlum et al., 2012; Scheresberg, 2013; Bapat, 2020). In addition, the investment sample of fewer than three years shows novice investors who still have little knowledge and experience about investing and finance so that they can be more easily influenced by news or posts on social media about stocks (Christanti \& Mahasanti, 2011; Fachrudin \& Fachrudin, 2016). In this study, the data is downloaded using partial least square structural equation modeling (PLS-SEM) with the smartPLS 3.0 program. Structural equation modeling SEM-PLS is a multivariate statistical technique that can analyze several variables at once. According to Hair Jr., Hult, Ringle, \& Sarstedt (2017), the SEM-PLS technique has the advantage of predicting well when problems occur such as small sample sizes, missing data, data not normally distributed, or when using latent variables.

\section{ANALYSIS AND DISCUSSION}

The data collection process was carried out using google forms questionnaire distributed through social media such as Line, Instagram, and Whatsapp. From 143 respondents who filled out the questionnaire, only 112 respondents met the sample criteria. The other 31 respondents did not meet the criteria. The result of outer model PLS on Figure 1.

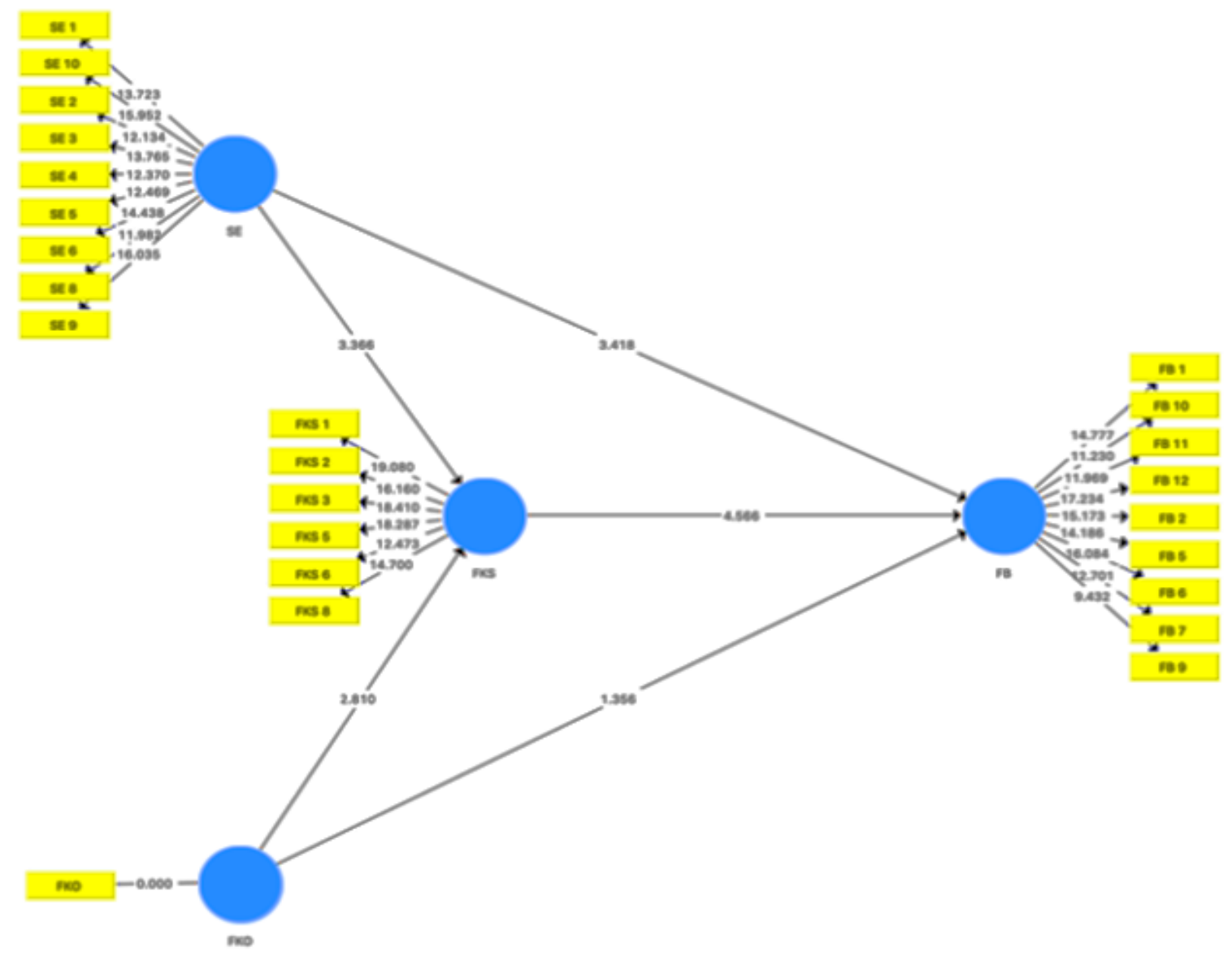

Figure 1. The Results of Path Coefficient 
Table 1. The Value of Outer Loadings

\begin{tabular}{cccc}
\hline Variable & Indicators & Outer Loadings & Description \\
\hline Self-Esteem & SE 1 & 0.703 & Valid \\
& SE 2 & 0.687 & Valid \\
& SE 3 & 0.721 & Valid \\
& SE 4 & 0.727 & Valid \\
& SE 5 & 0.706 & valid \\
& SE 6 & 0.706 & Valid \\
& SE 8 & 0.696 & Valid \\
& SE 9 & 0.717 & Valid \\
Objective Financial & SE 10 & 0.710 & Valid \\
Knowledge & FKO & 1,000 & Valid \\
\hline Subjective Financial & FKS 1 & 0.785 & Valid \\
Knowledge & FKS 2 & 0.771 & Valid \\
& FKS 3 & 0.783 & Valid \\
& FKS 5 & 0.812 & Valid \\
& FKS 6 & 0.726 & Valid \\
& FKS 8 & 0.766 & Valid \\
\hline Financial Behavior & FB 1 & 0.759 & Valid \\
& FB 2 & 0.714 & Valid \\
& FB 5 & 0.730 & Valid \\
& FB 6 & 0.759 & Valid \\
& FB 7 & 0.701 & Valid \\
& FB 9 & 0.661 & Valid \\
& FB 10 & 0.682 & Valid \\
& FB 11 & 0.735 & Valid \\
& FB 12 & 0.750 & Valid \\
\hline & & &
\end{tabular}

According to Hair Jr., Hult, Ringle, \& Sarstedt (2017), convergent validity indicates the level of an indicator that can measure a variable. This measurement is shown through the outer loading of each indicator and the average variance extracted (AVE) variable. The outer loading is considered invalid and cannot be used as variable indicators if the value is below $0.4(<0.4)$. Initially, this study had 32 indicators for measuring the variables. However, seven invalid indicators are SE 7, FKS 4, FKS 7, FB 3, FB 4, FB 8, and FB 13. AVE is acceptable if the value is > 0.5 (Hair Jr., Hult, Ringle, \& Sarstedt, 2017).

Table 2. The Reliability of Measurement Item

\begin{tabular}{lccc}
\hline \multicolumn{1}{c}{ Variable } & AVE & Cronbach's Alpha & Composite Reliability \\
\hline Self-Esteem & 0.502 & 0.877 & 0.901 \\
Financial Knowledge & 1,000 & 1,000 & 1,000 \\
Objectives & & 0.866 & 0.900 \\
Financial Knowledge & 0.599 & 0.885 & 0.907 \\
Subjective & 0.521 & Financial Behavior &
\end{tabular}

AVE variable can be accepted if it has a value above $0.5(>0.5)$. It can be seen from Table 2 that all variables have an AVE above 0.5 . Based on these results, it can be said that all indicators in this study are valid and meet the requirements of convergent validity.

According to Hair Jr., Hult, Ringle, \& Sarstedt (2017), discriminant validity is a measurement to see how much the indicator level of a variable differs from other variables in the research model $n$. In cross-loadings, the loading of an indicator of a variable on that variable must be higher than the loading of another variable. It can be seen from Table 3 that the cross-loadings value of each 
Table 3. The Value of Cross Loading

\begin{tabular}{ccccc}
\hline Indicators & SE & FKO & FKS & FB \\
\hline SE 1 & $\mathbf{0 , 7 0 3}$ & 0,231 & 0,291 & 0,358 \\
SE 2 & $\mathbf{0 , 6 8 7}$ & 0,274 & 0,186 & 0,179 \\
SE 3 & $\mathbf{0 , 7 2 1}$ & 0,187 & 0,272 & 0,355 \\
SE 4 & $\mathbf{0 , 7 2 7}$ & 0,151 & 0,365 & 0,350 \\
SE 5 & $\mathbf{0 , 7 0 6}$ & 0,146 & 0,168 & 0,379 \\
SE 6 & $\mathbf{0 , 7 0 6}$ & 0,136 & 0,200 & 0,329 \\
SE 8 & $\mathbf{0 , 6 9 6}$ & 0,180 & 0,266 & 0,197 \\
SE 9 & $\mathbf{0 , 7 1 7}$ & 0,254 & 0,384 & 0,300 \\
SE 10 & $\mathbf{0 , 7 1 0}$ & 0,190 & 0,238 & 0,274 \\
FKO & 0,267 & $\mathbf{1 , 0 0 0}$ & 0,338 & 0,299 \\
FKS 1 & 0,284 & 0,255 & $\mathbf{0 , 7 8 5}$ & 0,454 \\
FKS 2 & 0,346 & 0,207 & $\mathbf{0 , 7 7 1}$ & 0,341 \\
FKS 3 & 0,333 & 0,246 & $\mathbf{0 , 7 8 3}$ & 0,379 \\
FKS 5 & 0,232 & 0,296 & $\mathbf{0 , 8 1 2}$ & 0,370 \\
FKS 6 & 0,330 & 0,181 & $\mathbf{0 , 7 2 6}$ & 0,338 \\
FKS 8 & 0,264 & 0,379 & $\mathbf{0 , 7 6 6}$ & 0,349 \\
FB 1 & 0,316 & 0,157 & 0,343 & $\mathbf{0 , 7 5 9}$ \\
FB 2 & 0,373 & 0,288 & 0,353 & $\mathbf{0 , 7 1 4}$ \\
FB 5 & 0,308 & 0,315 & 0,395 & $\mathbf{0 , 7 3 0}$ \\
FB 6 & 0,296 & 0,177 & 0,393 & $\mathbf{0 , 7 0 1}$ \\
FB 7 & 0,326 & 0,116 & 0,293 & $\mathbf{0 , 6 6 1}$ \\
FB 9 & 0,182 & 0,197 & 0,263 & $\mathbf{0 , 6 8 2}$ \\
FB 10 & 0,338 & 0,123 & 0,222 & $\mathbf{0 , 7 3 5}$ \\
FB 11 & 0,279 & 0,198 & 0,419 & \\
FB 12 & 0,400 & 0,306 & 0,391 & \\
\hline
\end{tabular}

indicator has the loading highest on the variable. Therefore, all the variables of this study have met discriminant validity and are valid. Reliability tests can be measured through Cronbach's alpha and composite reliability of each latent variable. A variable is said to be reliable if its composite reliability is above the value of 0.6 (> 0.6) (Hair Jr., Hult, Ringle, \& Sarstedt, 2017). It can be seen from Table 2 that all variables from the study already have scores of Cronbach's alpha and composite reliability above 0.6 so that all variables from the study have met the requirement's reliability test and are declared reliable.

Evaluation of the inner model in PLS is done by looking at the R-Square value. This R-Square value is used to show how much the independent variable explains the dependent variable in this study. From the data processing results, the R-Square value for the variable financial knowledge subjective is 0.208 . This shows that the self-esteem and objective financial knowledge affect subjective financial knowledge by $20.8 \%$, while variables outside this study explain the remaining $79.2 \%$. Meanwhile, financial behavior variable has an R-Square value of 0.319 . This shows that the variables of selfesteem, objective financial knowledge, and subjective financial knowledge affect financial behavior by $31.9 \%$, while the remaining $68.1 \%$ is explained by variables outside this study.

Table 4. The Hypothesis Testing

\begin{tabular}{ccccc}
\hline & Original Sample & T Statistics & P Values & Description \\
\hline SE -> FB & 0.281 & 3,418 & 0.001 & Significant \\
FKO -> FB & 0.110 & 1,356 & 0.176 & Insignificant \\
FKS -> FB & 0.338 & 4,566 & 0.000 & Significant \\
SE -> FKS & 0.317 & 3,366 & 0.001 & Significant \\
FKO -> FKS & 0.254 & 2,810 & 0.005 & Significant \\
SE - > FKS -> FB & 0.086 & 2.604 & 0.009 & Significant \\
FKO -> FKS -> FB & 0.107 & 2.311 & 0.021 & Significant \\
\hline
\end{tabular}




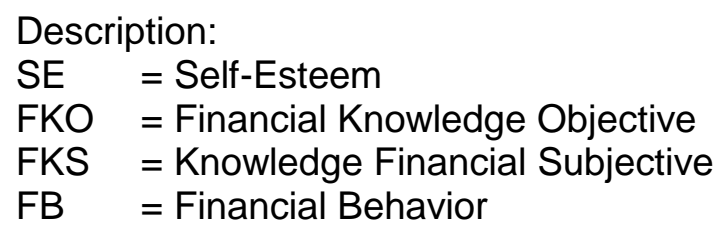

Hypothesis testing is done by bootstrapping on SmartPLS. The hypothesis will be accepted if the tcount (t-statistic) is 1.96 or P-Value $>0.05$. Based on Table 4 , self-esteem has a significant effect on financial behavior. Subjective financial knowledge has a significant effect on financial behavior. Self-esteem has a significant effect on subjective financial knowledge. The objective financial knowledge has a significant effect on the subjective financial knowledge. Self-esteem has a significant effect on financial behavior with subjective financial knowledge as a mediating variable and objective financial knowledge has a significant effect on financial behavior with subjective financial knowledge as a mediating variable. There is 1 hypothesis that is not significant, namely the effect of the objective financial knowledge on financial behavior.

From the results of this study, it was found that self-esteem has a significant effect on financial behavior in young adults in Surabaya. This finding is in line with the research results by Tang \& Baker (2016). This high self-esteem will be used as emotional resources for young adults such as perseverance and adaptability to get through the challenging financial management process. By going through various financial management processes, young adults can hone their behavior to make the right financial decisions, resulting in Financial Behavior in responsible.

Based on the results of research that has been done, it was found that objective financial knowledge had no significant effect on financial behavior in young adults in Surabaya. The results of this study are not in accordance with the research of Tang \& Baker (2016) and Javed, Degong, \& Qadeer (2017), which found a significant effect of objective financial knowledge on financial behavior. Tang \& Baker (2016) say that the effect of the objective financial knowledge can be insignificant because there is no subjective financial knowledge to help describe the effect of objective financial knowledge on financial behavior. However, this finding is in line with the results of research by Tang, Baker, \& Peter (2015), which found objective financial knowledge had no significant effect on financial behavior. According to Tang, Baker, \& Peter (2015), financial behavior is more closely related to a person's character, which is strongly influenced by psychological factors.

The results of data analysis found that self-esteem had a significant effect on the subjective financial knowledge of young adults in Surabaya. The results of this study are in line with research by Javed, Degong, \& Qadeer (2017). Young adults who have high self-esteem will give high value to themselves. As a result, carefully young adults also feel more confident in various aspects of themselves and place a high value on aspects such as financial knowledge. Based on the research conducted, the objective financial knowledge has a significant effect on subjective financial knowledge. This finding aligns with a study conducted by Ramalho \& Forte (2018). Therefore, young adults with high financial knowledge will have more confidence in their knowledge.

Based on data analysis, self-esteem has a significant effect on financial behavior, with subjective financial knowledge as a mediating variable. This finding is in line with the research of Tang \& Baker (2016). Therefore, having a good self-evaluation will carefully improve the evaluation of the financial knowledge of young adults. This high subjective financial knowledge will encourage young adults to find out financial information, deal with financial situations, and carry out financial management to build financial behavior more responsibly.

Based on data analysis, the objective financial knowledge has a significant effect on financial behavior, with subjective financial knowledge as a mediating variable. This finding is in line with the research of Tang \& Baker (2016). Young adults who have high knowledge of basic financial concepts will feel more confident in their knowledge, so that young adults will have high subjective financial knowledge. Having high subjective financial knowledge will encourage young adults to find out 
financial information, deal with financial situations, and carry out financial management to build financial behavior more responsibly.

\section{CONCLUSIONS AND RECOMMENDATIONS}

Based on the analysis conducted: First, self-esteem has a significant effect on financial behavior. Second, objective financial knowledge has no significant effect on financial behavior. Third, subjective financial knowledge has a significant impact on financial behavior. Fourth, self-esteem and objective financial knowledge significantly affect subjective financial knowledge. The last, selfesteem and objective financial knowledge have a significant effect on financial behavior with subjective financial knowledge as mediating variables. The limitations of this study are other factors such as other psychological factors and social factors, so it is recommended for further research to use these factors. In addition, it is hoped that further research will examine the profile of respondents with more specific educational backgrounds and use more relevant questions between each variable, such as between objective financial knowledge and financial behavior.

\section{REFERENCES}

Abreu, M., \& Mendes, V. (2012). Information, Overconfidence, and Trading: Do the Sources of Information Matter?. Journal of Economic Psychology, Vol. 33, 868-881.

Alba, J.W., \& Hutchinson, JW (2000). Knowledge Calibration: What Consumers Know and What They Think They Know. Journal of Consumer Research, Inc, Vol. 27, 123-156.

Arnett, J.J., Ukauskienè, R., \& Sugimura, K. (2014). The New Life Stage of Emerging Adulthood at Ages 1829 Years: Implications for Mental Health. The Lancet Psychiatry 1, 569-576.

Bandura, A. (1982). Self-Efficacy Mechanism in Human Agency. American Psychologist Association Vol. 37, 122-147.

Bapat, D. (2020). Antecedents to Responsible Financial Management Behavior among Young Adults: Moderating Role of Financial Risk Tolerance". International Journal of Bank Marketing, 38(5), 1177-1194.

Basana, S.R., \& Tarigan, Z.J.H. (2021). The Effect of Essential Information and Disposition Effect on Shifting Decision Investment. Accounting 8(2), 264-276, 10.5267/j.ac.2021.6.015.

Christanti, N., \& Mahasanti, L.A. (2011). The Factors That Investors Consider in Making an Investment. Journal of Theoretical and Applied Management Year, 4(3), 37-51.

Claudia, C., \& Evelyn. (2021). The Influence of Emerging Adulthood Status and Sensation Seeking on Financial Behavior of Petra Christian University Students. International Journal of Financial and Investment Studies, 1(2), 94-100. https://doi.org/10.9744/ijfis.1.2.94-100.

Dew, J., \& Xiao, J.J. (2011). Financial Management Behavior Scale: Development and Validation. Journal of Financial Counseling and Planning, 22(1), 43-59.

Fachrudin, K., \& Fachrudin, K. (2016). The Influence of Education and Experience toward Investment Decisions with Moderated by Financial Literacy. Polish Journal of Management Studies, 51-60.

Febrian, A. (2021, February 5). Millennial Investors Dominate The Capital Market, OJK Warns Not To Fall for The Pompom Action. Retrieved from Investasi.Kontan.co.id: https://investasi.kontan.co.id/news/investormillennial-mendominat-pasar-modal-ojk-ingatkan-jangan-termakan-aksi-pompom

Gabriel, F., \& Linawati, N. (2020). Pengaruh Financial Capability, Money Attitudes, dan Socioeconomic Status terhadap Adverse Financial Events. International Journal of Financial and Investment Studies, 1(1), 15-20. https://doi.org/10.9744/ijfis.1.1.15-20.

Hair Jr., J.F., Hult, G.T., Ringle, C.M., \& Sarstedt, M. (2017). A Primer on Partial Least Squares Structural Equation Modeling (PLS-SEM) (2nd Edition Ed.). Los Angeles: SAGE.

Hilgert, M.A., Hogarth, J.M., \& Beverly, S.G. (2003). Household Financial Management: The Connection between Knowledge and Behavior. Federal Reserve Bulletin, 309-322.

Javed, M.K., Degong, M., \& Qadeer, T. (2017). Importance of Financial Knowledge and Self-Esteem in Determining Individual's Financial Behavior. Proceedings of Academics World 76th International Conference, 56-59

Lind, T., Ahmed, A., Skagerlund, K., Strömbäck, C., Västfjäll, D., \& Tinghög, G. (2020). Competence, Confidence, and Gender: The Role of Objective and Subjective Financial Knowledge in Household Finance. Journal of Family and Economics, 41(2).

Ludlum, M., Tilker, K., Ritter, D., Cowart, T., Xu, W., \& Smith, BC (2012). Financial Literacy and Credit Cards: A Multicampus Survey. International Journal of Business and Social Science, 3(7), 25-33.

Mahrofi, Z. (2021, January 14). Be Careful, Don't Be Tempted by Influencer-Style Stock "Pompoms". Retrieved from Antara News: https://www.antaranews.com/berita/1946532/waspada-jangan-tergiur-pompom-sahamala-influencer 
Malelak, M. I., \& Halim, N.M. (2021). Spending Patterns on Millennial Generation in Surabaya. International Journal of Financial and Investment Studies, 2(1), 20-26. https://doi.org/10.9744/ijfis.2.1.20-26

Nurdiana, A. (2021, February 27). The Phenomenon of Investment Pom-Poms and Novice Investors on the IDX. Retrieved from Investasi.Kontan.co.id: https://investasi.kontan.co.id/news/fenomena-pom-pominvestasi-dan-investor-pemula-di-bei-1 ?page $=1$

Perry, V., \& Morris, M. (2005). Who is in Control? The Role of Self-Perception, Knowledge, and Income in Explaining Consumer Financial Behavior. The Journal of Consumer Affairs, 39(2), 299-313.

Ramadhan, A.Y., \& Asandimitra, N. (2019). Determinants of Financial Management Behavior of Millennial Generation in Surabaya. Journal of Minds: Management of Ideas and Inspiration, 6(2), 129-144.

Ramalho, T.B., \& Forte, D. (2018). Financial Literacy in Brazil - Do Knowledge and Self-Confidence Relate to Behavior?. RASP Management Journal, 77-95.

Rizkiawati, N.L., \& Asandimitra, N. (2018). The Influence of Demographics, Financial Knowledge, Financial Attitude, Locus of Control, and Self-Efficacy on the Financial Management Behavior of the People of Surabaya. Journal of Management Science, 6(3), 93-107.

Rosenberg, M. (1965). Society and the Adolescent Self-Image. Princeton, New Jersey: Princeton University Press.

Rosenberg, M., Schooler, C., Schoenbach, C., \& Rosenberg, F. (1995). Global Self-Esteem and Specific SelfEsteem: Different Concepts, Different Outcomes. American Sociological Review, 60, 141-156.

Sawitri, N.N. (2018). Behavior in Managing Revenue to Achieve Financial Satisfaction. Opcion, Año, 34(86), $1274-1291$.

Scheresberg, C. D. (2013). Financial Literacy and Financial Behavior among Young Adults: Evidence and Implications. Numeracy, 6(2), DOI: http://dx.doi.org/10.5038/1936-4660.6.2.5

Schwab Moneywise. (2009). Charles Schwab 2009 Young Adults \& Money Survey Findings. Retrieved from Schwab Moneywise: https:/www.schwabmoneywise.com/public/file/P-4065778/YoungAdults_and_MoneyFactSheet.pdf

Srivastava, N., \& Agarwal, D.S. (2013). Self-Esteem among Young Adults- A Comparative Study. International Journal of Humanities and Social Science Invention, 2(3), 59-61.

Sugiyono. (2019). Quantitative, Qualitative, and R\&D Research Methods - MPKK. Bandung: Alphabeta.

Tang, N., \& Baker, A. (2016). Self-Esteem, Financial Knowledge and Financial Behavior. Journal of Economic Psychology 54, 164-176.

Tang, N., Baker, A., \& Peter, P.C. (2015). Investigating the Disconnect between Financial Knowledge and Behavior: The Role of Parental Influence and Psychological Characteristics in Responsible Financial Behaviors among Young Adults. The Journal of Consumer Affairs, Summer 2015, 376-406.

Topa, G., Hernández-Solís, M., \& Zappalà, S. (2018). Financial Management Behavior among Young Adults: The Role of Need for Cognitive Closure in A Three-Wave Moderated Mediation Model. Front. Psychol. 9:2419.

Twenge, J.M., \& Campbell, W.K. (2001). Age and Birth Cohort Differences in Self-Esteem: A Cross-Temporal Meta-Analysis. Personality and Social Psychology Review, 5(4), 321-344.

Van R., M., Lusardi, A., \& Alessie, R. (2011). Financial Literacy and Stock Market Participation. Journal of Financial Economics 101, 449-472.

Wareza, M. (2021, January 18). Oh No! Many Stock Investments from Borrowing \& Pawning BPKB. Retrieved from CNBC Indonesia: https://www.cnbcindonesia.com/market/20210118100942-17-216739/oh-no-banyak-investasisaham-dari-utang-pinjol-gadai-bpkb

Xiao, J.J. (2008). Applying Behavior Theories to Financial Behavior. Handbook of Consumer Finance Research, 69-81. 